\title{
Sequence Variants in BMPR2 and Genes Involved in the Serotonin and Nitric Oxide Pathways in Idiopathic Pulmonary Arterial Hypertension and Chronic Thromboembolic Pulmonary Hypertension: Relation to Clinical Parameters and Comparison with Left Heart Disease
}

\author{
Silvia Ulrich ${ }^{\mathrm{a}}$ Justyna Szamalek-Hoegel ${ }^{\mathrm{b}}$ Martin Hersberger ${ }^{\mathrm{a}} \quad$ Manuel Fischler $^{\mathrm{a}}$ \\ Jesus Solera Garciab Lars C. Huber ${ }^{a}$ Ekkehard Grünig ${ }^{c}$ Bart Janssen ${ }^{b}$ \\ Rudolf Speich ${ }^{\mathrm{a}}$ \\ ${ }^{a}$ Clinic of Internal Medicine, University Hospital of Zurich, Zurich, Switzerland; ${ }^{b}$ Institute of Human Genetics, \\ University of Heidelberg, and ${ }^{\mathrm{C}}$ Thoraxklinik Heidelberg, Heidelberg, Germany
}

For editorial comment see p. 274

\section{Key Words}

Bone morphogenetic protein · Chronic thromboembolic pulmonary hypertension $\cdot$ Genetics $\cdot$ Idiopathic pulmonary arterial hypertension $\cdot$ Nitric oxide $\cdot$ Pulmonary

hypertension $\cdot$ Serotonin

\begin{abstract}
Background: Idiopathic pulmonary arterial hypertension (IPAH) and chronic thromboembolic pulmonary hypertension (CTEPH) share important pathogenic and clinical features. BMPR2 mutations are important in the pathogenesis of IPAH, but little is known about the genetic background in CTEPH. Objective: To search for mutations and polymorphisms in genes involved in the BMPR2, serotonin and nitric oxide pathways possibly associated with pulmonary and cardiac disorders in IPAH and CTEPH. Methods: In a cohort of Swiss patients with IPAH $(n=16)$ and CTEPH $(n=16)$, and in 24 controls with left heart disease without $\mathrm{PH}$, polymorphisms in the BMPR2, 5-HHT, 5-HTR-2A and eNOS genes were analyzed and correlated with various clinical, functional and
\end{abstract}

\section{KARGER}

Fax +41613061234 E-Mail karger@karger.ch www.karger.com (c) 2009 S. Karger AG, Basel

$0025-7931 / 10 / 0794-0279 \$ 26.00 / 0$

Accessible online at:

www.karger.com/res hemodynamic parameters. Results: We found a BMPR2 missense mutation in a patient with coronary artery disease (CAD) without PH but no BMPR2 mutations in our collective with late-onset sporadic $\mathrm{PH}$. In patients with polymorphic variants of the BMPR2 gene, the number of blood platelets and oxygen saturation were increased. The c.600A $\rightarrow C$ synonymous variant was associated with worse exercise capacity and decreased quality of life in $\mathrm{PH}$. We found no significant differences for any measured parameter according to the eNOS, 5-HTR2A and the 5-HTT polymorphisms, although there was a higher allelic frequency of the 5-HTT long variant in IPAH than in CTEPH and controls. Conclusion: Our first report of a BMPR2 mutation in a patient with CAD without $\mathrm{PH}$ is interesting and warrants further investigation. Our study may reflect the clinical status and genetic background in a typical PH cohort as seen in a single tertiary care referral center.

Copyright $\odot 2009$ S. Karger AG, Basel
Silvia Ulrich, MD

Department of Medicine and Pulmonology, University Hospital of Zurich

Rämistrasse 100

CH-8091 Zurich (Switzerland)

Tel. +41 4425543 62, Fax +41 4425544 15, E-Mail silvia.ulrich@usz.ch 


\section{Introduction}

Idiopathic pulmonary arterial hypertension (IPAH) and chronic thromboembolic pulmonary hypertension (CTEPH) belong to the group of pulmonary vascular disorders classified by the World Health Organization and defined by mean pulmonary artery pressure $\geq 25 \mathrm{~mm} \mathrm{Hg}$ at rest [1]. Structural and functional changes in the vascular wall and thrombus formation are the main factors responsible for increased pulmonary vascular resistance in patients with pulmonary hypertension $(\mathrm{PH})[2,3]$. The contribution of each of these factors is thought to be different among the variable underlying causes of $\mathrm{PH}$ [4]. Despite these presumptive distinctions, differently classified PH such as IPAH and CTEPH share important pathogenetic and clinical features. Favorable effects of vasodilator and antiproliferative agents are not only seen in IPAH but also in CTEPH [5-9]: both disorders share acute vasodilator properties [10] and a comparable pulmonary vessel histology at advanced disease [11].

Since the description of heterozygous mutations in the bone morphogenetic protein type II receptor (BMPR2 gene) in patients with $\mathrm{PH}[12,13]$, it has become widely accepted that alternations in the transforming growth factor (TGF)- $\beta$ pathway, to which BMPR2 belongs, play an important role in $\mathrm{PH}$ development [14-16]. Although BMPR2 mutations are the underlying cause in $>70 \%$ of familial and $11-26 \%$ of sporadic IPAH cases $[12-14,17$, 18], only a minority of patients with BMPR2 mutations develop clinical $\mathrm{PH}$ due to markedly reduced penetrance $[14,19,20]$.

Hence, there must be other factors which, in addition to or in combination with the BMPR2 mutations, play a pathogenetic role in the development of $\mathrm{PH}$. These second or third pathogenetic 'hits' might be other genetic or environmental factors, or both interplaying with each other. In this study, we aimed to investigate some genetic factors possibly contributing to the pathogenesis of the two major forms of PH (IPAH and CTEPH).

Beside some rare cases of $B M P R 2$ mutations found in patients with congenital heart disease-associated $\mathrm{PH}$ [21] and pulmonary veno-occlusive disease [22, 23], little is known about $B M P R 2$ mutations in other forms of $\mathrm{PH}$, e.g. CTEPH. A recent British study characterizing CTEPH patients did not find BMPR2 mutations in $>100$ subjects [24].

Among other genetic factors, which were suggested to affect the pathogenesis of $\mathrm{PH}$, there are polymorphisms in the serotonin transporter (5-HTT) or receptor (5-HTR) genes or, in analogy to left heart diseases, polymorphisms in the nitric oxide (NO) system $[2,25,26]$. The long allelic variant in 5-HTT has been found to be associated with $\mathrm{PH}$ severity in patients with chronic obstructive pulmonary disease [27] but not in IPAH [28]. 5-HTR has been reported to play an important role in vasoconstriction and proliferation of vessel walls [29]. The c.102T $\rightarrow C$ polymorphism of the 5-HTR $2 A$ gene has been associated systemic arterial hypertension [30-32] but has not been investigated in $\mathrm{PH}$. Therefore, we decided to include this gene in our analysis. NO plays a key role in endothelial dysfunction [33], and the expression of the endothelial NO synthase (eNOS) is modified in PH [34]. Polymorphisms in the eNOS gene have been related to coronary artery disease (CAD) [35] and to high-altitude pulmonary edema in Japanese and Indian populations [36, 37] but not in Caucasians [38]. At this background, we have chosen to investigate the $4 a / b$ and the p.Glu298Asp polymorphisms of eNOS in our patient cohort.

The aim of the present study was to prospectively investigate genetic variants in $B M P R 2$ and some potentially interesting variants in 5-HTT, 5-HTR2A and eNOS in consecutive patients with IPAH and CTEPH and to look for associations with clinical, functional and hemodynamic parameters. As controls, exercise-limited patients with left heart disease not suffering from $\mathrm{PH}$ were included.

\section{Patients and Methods}

\section{Study Population}

Between October 2004 and May 2006, consecutive patients with IPAH and CTEPH seen at the PH clinic of the University Hospital of Zurich, Switzerland, were prospectively included upon written informed consent. PH was defined as mean pulmonary arterial pressure $\geq 25 \mathrm{~mm} \mathrm{Hg}$ with a pulmonary capillary occlusion pressure $\leq 15 \mathrm{~mm} \mathrm{Hg}$ by right heart catheterization. IPAH was diagnosed if a thorough evaluation by medical history, echocardiography, rheumatologic examination, antibody screening and additional tests if required according to best clinical practice (e.g. pulmonary function tests, blood gas assessment, thoracic computed tomography, coronary angiography and rheumatologic evaluation) did not reveal any other cause for elevated pulmonary pressure [1]. In every patient, a detailed family history has been obtained, and a pedigree has been constructed. CTEPH was diagnosed by both radioisotope ventilation-perfusion scan and pulmonary angiography [39].

In the control patients, $\mathrm{PH}$ was excluded either by heart catheterization or echocardiography, and assessment of genetics, and clinical and functional parameters was similar to the $\mathrm{PH}$ group. The study was approved by the local ethics committee. 
Table 1. PCR and sequencing primers used for the $B M P R 2$ mutation analysis

\begin{tabular}{llll}
\hline BMPR2 exon & Forward primer $\left(5^{\prime} \rightarrow 3^{\prime}\right)$ & Reverse primer $\left(5^{\prime} \rightarrow 3^{\prime}\right)$ & $\begin{array}{l}\text { Annealing } \\
\text { temperature, }{ }^{\circ} \mathrm{C}\end{array}$ \\
\hline 1 & gtgatacgggcaggatcagt & atttcctggaaggcatgg & 61 \\
2 & gtcattcggataagacaaa & tttaacatactcccatgtcc & 54 \\
3 & tagcttacacgtactctcac & cctggcttcaaccttgaatg & 58 \\
4 & gggtacagcctttctaaagg & gatactattgaggctgggtg & 61 \\
4 (sequencing primer) & tgacatttcaaaatttgtttcttt & & \\
5 & gctgctaatctttctgcagc & gaatgaagtcactgttccag & 61 \\
6 & cagagagctgtagcattctg & aagtgatccacctgccttag & 58 \\
7 & tttgcaaattctttataaggatgc & ttcctgttgtgaattttgaacc & 56 \\
7 (sequencing primer) & cgcatttttcctctata & & \\
8 & gttattagaaaattaatgggcaga & ttatcatttcaaagtacatcagtg & 56 \\
9 & agaatatgctacgttctctc & acactagatagcaatgaactaaagg & 56 \\
10 & ttggtatcagaaataccctgtt & caaacaacattaaaacatattcagtca & 56 \\
11 & cacatggtttgacatgtactttg & tcattgaactattaggctggttt & 54 \\
12 (fragment 12-1) & aaatttggagagacagtttgtca & ttcatctgggtatggcatctc & 58 \\
12 (fragment 12-2) & agcaagcacaagctcgaatc & agtcctgctgtcagttgct & 58 \\
12 (fragment 12-3) & tctagcttgctttacccact & agcatgggagttaacactgt & 58 \\
12 (fragment 12-4) & acctcatgtggtgacagtca & attggaattagttcggccac & 56 \\
12 (fragment 12-5) & attcagtcctgatgagcat & agttattaaatggcccaa & 56 \\
13 & caccctctgagacattggt & catcttctgcatgtttaaatga & 55 \\
\hline
\end{tabular}

\section{General Study Assessments}

Patient's demographics (age, sex, height, weight and calculated body mass index in $\mathrm{kg} / \mathrm{m}^{2}$ ), history, drug use, New York Heart Association (NYHA) functional class, 6-min walk distance (6MWD) and Borg dyspnea scale score were assessed. Quality of life (QoL) was measured by the Minnesota Living with Heart Failure Questionnaire, with higher scores representing worse QoL [40]. NT-pro brain natriuretic peptide, C-reactive protein (using a highly sensitive method, CRPsens), uric acid, creatinine, albumin, bilirubin, calcium, and erythrocyte, leukocyte and thrombocyte counts were assessed.

\section{Genetic Analysis}

EDTA-supplemented blood samples were collected and DNA was extracted with the QIAamp ${ }^{\circledR}$ DNA Mini Kit (Qiagen, Basel, Switzerland). Primers were designed with the Oligo 4.0 software (MedProbe, Oslo, Norway) and with the Primer3 Program (http:// primer3.sourceforge.net/), and purchased from Microsynth (Balgach, Switzerland) or from Eurofins MWG Operon (Ebersberg, Germany).

\section{BMPR2 Mutation and Polymorphism Analysis}

$B M P R 2$ mutation analysis was performed in the Institute of Human Genetics in Heidelberg in all index patients and controls using denaturating high-performance liquid chromatography and cycle sequencing with the BigDye terminator kit (V1.1, Applied Biosystems, Darmstadt, Germany) on an ABI 3700 sequencer as described previously (table 1) [17]. Genetic investigators were blinded to the clinical data. To determine the significance of the c. $818 \mathrm{~T} \rightarrow \mathrm{G}$ (p.Met273Arg) mutation for pre-mRNA splicing, the
BMPR2 transcript was analyzed by RT-PCR as previously described [17].

\section{5-HTT Polymorphisms}

The 44-bp insertion/deletion polymorphism in 5-HTT was analyzed using 5-HTT primers and the Expand Long Template Kit from Roche Molecular Biochemicals (Rotkreuz, Switzerland). PCR resulted in a long (L) amplification product of $457 \mathrm{bp}$ and in a short (S) amplification product of $414 \mathrm{bp}$ for the two alleles, which were separated on agarose gels.

c.102T $\rightarrow$ C Polymorphism of HTR2A

For the detection of the $\mathrm{c} .102 \mathrm{~T} \rightarrow \mathrm{C}$ polymorphism in the HTR2A gene, a LightCycler assay was developed and four oligonucleotides were added to the LightCycler DNA Master Hybridization Probes mixture (Roche Molecular Biochemicals); a melting curve analysis was performed from 40 to $85^{\circ} \mathrm{C}$ at a linear rate of $0.1^{\circ} \mathrm{C} / \mathrm{s}$ [41].

\section{4a/b Polymorphism of eNOS}

eNOS4a is a rare short allele with 4 tandem 27-bp repeats and eNOS $4 \mathrm{~b}$ is a large allele with 5 tandem repeats. Genotyping of the $27-b p$ repeat in intron 4 of the eNOS gene (eNOS4a/b) was performed according to Wang et al. [42].

\section{Glu298Asp Polymorphism of eNOS}

For the detection of the p.Glu298Asp polymorphism in eNOS, a 25- $\mu$ l tetraprimer PCR was developed using the Amplitaq Gold $^{\text {TM }}$ System (Perkin-Elmer, Hünenberg, Switzerland) and applied as previously described $[43,44]$. 
Table 2. Characteristics of the patients and controls

\begin{tabular}{|c|c|c|c|}
\hline Characteristics & IPAH $(n=16)$ & CTEPH $(\mathrm{n}=16)$ & Controls $(\mathrm{n}=24)$ \\
\hline \multicolumn{4}{|l|}{ General } \\
\hline Sex, females/males & $10 / 6$ & $9 / 7$ & $9 / 15$ \\
\hline \multicolumn{4}{|l|}{ Age, years } \\
\hline At study assessment & $65 \pm 16$ & $65 \pm 11$ & $67 \pm 12$ \\
\hline At first PH-related symptoms & $62 \pm 16$ & $62 \pm 12$ & \\
\hline NYHA functional class, II/III/IV & $1 / 8 / 7$ & $1 / 10 / 4$ & $1 / 10 / 13$ \\
\hline 6MWD, m & $348 \pm 85$ & $435 \pm 64^{*}$ & $288 \pm 93^{* *}$ \\
\hline \multicolumn{4}{|l|}{ QoL, points } \\
\hline Total & $44 \pm 15$ & $36 \pm 19$ & $42 \pm 21$ \\
\hline Physical subscore & $24 \pm 7$ & $20 \pm 6$ & $24 \pm 10$ \\
\hline Emotional subscore & $9 \pm 6$ & $10 \pm 7$ & $6 \pm 7$ \\
\hline Pro-BNP $(<88$ ng/l) & $2,303 \pm 1,810$ & $2,099 \pm 1,576$ & $3,617 \pm 3,501$ \\
\hline Uric acid $(150-300 \mu \mathrm{mol} / \mathrm{l})$ & $462 \pm 144$ & $470 \pm 140$ & $488 \pm 178$ \\
\hline \multicolumn{4}{|l|}{ Pulmonary hemodynamics } \\
\hline Mean pulmonary arterial pressure, $\mathrm{mm} \mathrm{Hg}$ & $48 \pm 10$ & $41 \pm 10$ & \\
\hline Pulmonary vascular resistance, $\mathrm{dyn} \cdot \mathrm{s} \cdot \mathrm{cm}^{5}$ & $748 \pm 361$ & $708 \pm 293$ & \\
\hline Cardiac index, $1 / \mathrm{min} / \mathrm{m}^{2}$ & $2.3 \pm 0.7$ & $2.0 \pm 0.5$ & \\
\hline Right atrial pressure, $\mathrm{mm} \mathrm{Hg}$ & $12 \pm 7$ & $11 \pm 8$ & \\
\hline Mixed venous oxygen saturation, $\%$ & $58 \pm 9$ & $55 \pm 8$ & \\
\hline
\end{tabular}

Means $\pm \mathrm{SD} .{ }^{*} \mathrm{p}<0.05$ vs. IPAH, ${ }^{* *} \mathrm{p}<0.001$, vs. IPAH and CTEPH. Normal range/values are shown in parentheses.

Statistical Analysis

Results are expressed as medians (interquartile ranges) or means $\pm \mathrm{SD}$. The Mann-Whitney $\mathrm{U}$ test and analysis of variance were used to compare means between groups. Fisher's exact test was applied to compare frequencies between groups. Differences of $\mathrm{p}<0.05$ were considered statistically significant.

\section{Results}

\section{Patient Characteristics}

PH Study Group. Of the $38 \mathrm{PH}$ patients screened, 6 patients were excluded for reasons other than $\mathrm{PH}$ (2 patients with scleroderma and 4 with left heart dysfunction). We finally included 16 patients (10 females) with IPAH (age $65 \pm 16$ years) and 16 patients (9 females) with CTEPH (age $65 \pm 11$ years) in the study (table 2). All patients are Caucasians. Twenty-four patients were included at the time of their first confirmatory right heart catheterization and 8 patients at the time of a follow-up catheterization. On average, symptoms had started $15 \pm 11$ months before diagnosis. All patients were followed up in our $\mathrm{PH}$ clinic (mean follow-up time $37 \pm 20$ months until data analysis). Six patients died (33 \pm 32 months after diagnosis), and 3 patients had successful pulmonary endar- terectomy. All IPAH patients had a negative family history of the disease. Nine of the CTEPH patients were classified as operable by a specialized surgeon (E. Mayer, Mainz); however, 6 were not operated on due to patients' wishes or comorbidity. Most patients were in NYHA class III or IV. IPAH patients had a significantly lower 6MWD compared with CTEPH patients but comparable QoL, pro-BNP, uric acid and pulmonary hemodynamics (table 2).

Control Group and Comparison with All PH Patients. Twenty-four patients ( 9 females; age $67 \pm 12$ years) without $\mathrm{PH}$ (7 with valvular, 8 with ischemic and 9 patients with hypertensive heart disease) were included as controls. PH was excluded by heart catheterization or echocardiography.

\section{Genetic Analysis}

BMPR2 Sequence Variants

In the present collective, no BMPR2 mutations were found in the 16 study patients with sporadic IPAH and in the 16 patients with CTEPH. Interestingly, a c.818T $\rightarrow \mathrm{G}$ (p.Met273Arg) mutation was noted in a patient with CAD and impaired left ventricular pump function without $\mathrm{PH}$ (initial right ventricular pressure $26 \mathrm{~mm} \mathrm{Hg}$ above the 
Table 3. $B M P R 2$ sequence variants found in the Swiss collective and their frequency distribution within groups

\begin{tabular}{|c|c|c|c|c|c|}
\hline \multirow[t]{2}{*}{ Location } & \multirow{2}{*}{$\begin{array}{l}\text { Nucleotide } \\
\text { change }\end{array}$} & \multirow{2}{*}{$\begin{array}{l}\text { Amino } \\
\text { acid change }\end{array}$} & \multicolumn{3}{|c|}{ Frequencies, \% } \\
\hline & & & IPAH & СТЕРН & controls \\
\hline $\begin{array}{l}\text { Intron } 3 \\
\text { and } 4\end{array}$ & $\begin{array}{l}\text { c. } 420-38 \text { delT; } \\
\text { c.529+64C } \rightarrow \mathrm{T}\end{array}$ & & 15 & 20 & 17 \\
\hline Exon 5 & c. $600 \mathrm{~A} \rightarrow \mathrm{C}$ & p.L200L & 20 & 0 & 4 \\
\hline Exon 6 & c. $818 \mathrm{~T} \rightarrow \mathrm{G}$ & p.M273R & 0 & 0 & 4 \\
\hline Exon 12 & c. $2324 \mathrm{G} \rightarrow \mathrm{A}$ & p.S775N & 0 & 13 & 4 \\
\hline Exon 12 & c. $2811 \mathrm{G} \rightarrow \mathrm{A}$ & p.R937R & 20 & 20 & 38 \\
\hline
\end{tabular}

right atrial pressure by echocardiography). This patient underwent coronary angioplasty and stenting of his left anterior descending artery due to a non-ST elevation myocardial infarction. Two years later, he received aortocoronary bypass surgery, and after recovery he was classified in NYHA functional class I. His echocardiographically measured right ventricular pressure was $19 \mathrm{~mm} \mathrm{Hg}$ 3 months after the operation. At the last follow-up, he felt well (48 months after inclusion) without any relevant dyspnea (NYHA I). His family history was negative for $\mathrm{PH}$, dyspnea, sudden deaths or syncopes. The c.818T $\rightarrow \mathrm{G}$ (p.Met273Arg) mutation was proven in two independent blood samples. According to the in silico analysis performed with the use of the web resource ESEfinder, this missense mutation was predicted to alternate the sequence of exonic splicing enhancers. For verification, we have conducted RT-PCR analysis on the mRNA of the patient and found that the mutation was also present in the BMPR2 transcript and did not influence the proper splicing. Nevertheless, the possibility remains that this methionine $\rightarrow$ arginine exchange affects the function of the BMPR2 receptor. This exchange occurred within the kinase domain of the BMPR2 receptor in an evolutionary highly conserved region of the gene.

Several intronic and coding polymorphisms of the $B M P R 2$ gene have been reported so far [23]. In our collective, we detected $B M P R 2$ polymorphisms in introns 3 and 4 , and exons 5 and 12 (table 3). The c.600A $\rightarrow$ C (p.L200L) polymorphism in exon 5 was thereby almost exclusively found in IPAH (3 patients), while the c.2324G $\rightarrow \mathrm{A}$ (p.S775N) polymorphism from exon 12 was detected in CTEPH patients. The other BMPR2 polymorphisms were found with almost equal distribution between the groups. Overall, $\mathrm{PH}$ patients with any BMPR2 polymorphisms had lower blood platelet counts and higher oxy-

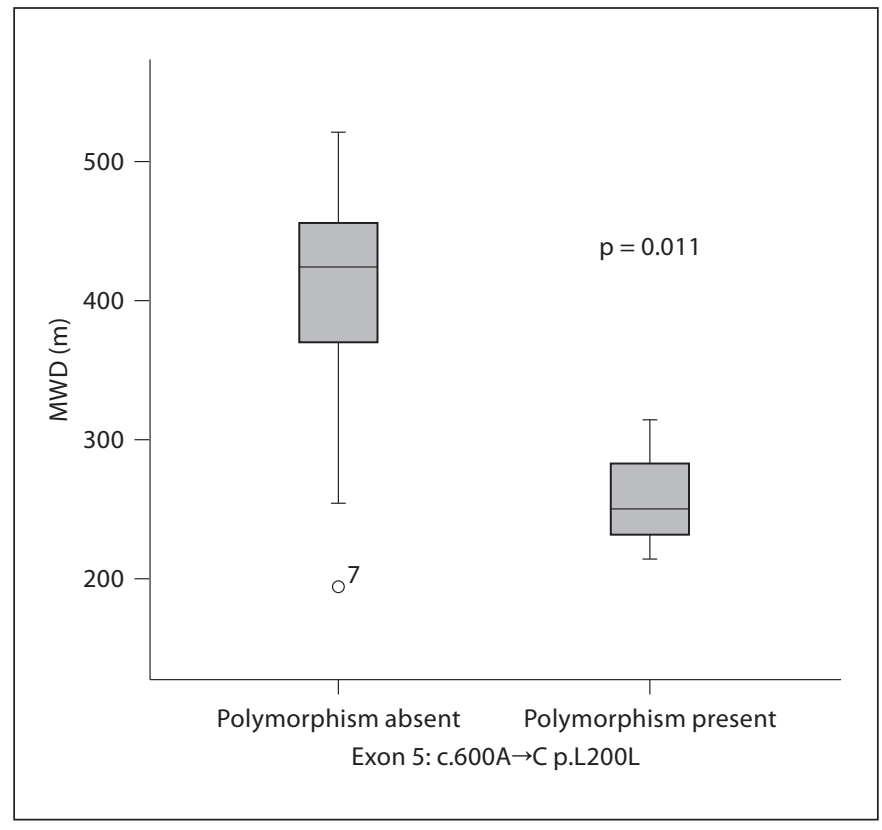

Fig. 1. $6 \mathrm{MWD}$ according to the p.L200L BMPR2 polymorphism in patients with $\mathrm{PH}$.

gen saturations than patients with the wild-type sequence ( 269 vs. $210 \cdot 10^{3} / \mu l, p=0.025$, and 87.5 vs. $\left.91 \%, p=0.028\right)$. IPAH patients with disease onset below the age of 60 years $(n=4)$ were more likely to carry any sequence variants than patients with a later disease onset ( $>60$ years, $\mathrm{n}=12$ ): $4 / 4$ versus $4 / 12$. Polymorphisms in CTEPH patients were more equally distributed for patients with an earlier $(n=6)$ versus late disease onset $(n=10): 2 / 6$ versus $6 / 10$. PH patients carrying the c.600A $\rightarrow$ C (p.L200L) sequence variant had a significantly lower $6 \mathrm{MWD}$ and worse physical subscores in QoL assessments (mean 6MWD 259 vs. $408 \mathrm{~m}, \mathrm{p}=0.011$, and mean physical QoL score 30 vs. 21 points, $\mathrm{p}=0.022$; fig. 1 ). Two patients were acute responders to inhaled NO during heart catheterization, and both did not have BMPR 2 polymorphisms. Four of the 6 patients $(67 \%)$ who died and 10 of the 26 patients (38\%) who survived until the end of the study had any $B M P R 2$ polymorphism. Event-free survival did not differ between carriers of any BMPR2 polymorphism and noncarriers until the end of the study.

\section{Polymorphism of 5-HTT}

The long allelic variant of the 5-HTT gene was found homozygous in 33, 6 and 20\% and heterozygous in 47, 69 and $54 \%$ of patients with IPAH, CTEPH and controls, 
respectively (nonsignificant; table 4). The allelic frequency of the L variant was slightly higher in IPAH than in CTEPH and in control groups (nonsignificant). There were no significant differences in patient characteristics according to the 5-HTT polymorphism overall and within each group. Of the patients who succumbed, the long allelic variant was found homozygous in 1 and heterozygous in 2 patients.

\section{c. $102 \mathrm{~T} \rightarrow \mathrm{C}$ Polymorphism of 5-HTR2A}

The frequencies of the TT, TC and CC variants in IPAH, CTEPH and controls are shown in table 4 . The allelic frequency for the $\mathrm{C}$ and $\mathrm{T}$ alleles was similar in all groups. No significant differences regarding 5-HTR2A variants were found for any parameter measured.

\section{eNOSb/a}

The eNOS4a allele was found heterozygous in 33,31 and $29 \%$ of IPAH, CTEPH and controls and homozygous in 0,6 and $4 \%$, respectively (table 4 ). The allelic frequencies of the eNOS4a variant were 17, 22 and 19\% in IPAH, $\mathrm{CTEPH}$ and controls, respectively. $\mathrm{PH}$ patients with the eNOS4a variant tended to have higher pulmonary vascular resistances $\left(618,769\right.$ and $1,105 \mathrm{dyn} \cdot \mathrm{s} \cdot \mathrm{m}^{-5}$ for $\mathrm{bb}, \mathrm{ab}$ and aa, respectively) and lower 6MWD (432, 409 and $413 \mathrm{~m}$ for $\mathrm{bb}, \mathrm{ab}$ and aa, respectively), but the differences did not reach statistical significance in this relatively small cohort.

\section{Endothelial NO p.Glu298Asp Polymorphism}

As shown in table 4, the genotype frequencies for p.Glu298Glu, p.Glu298Asp and p.Asp298Asp were 27, 53 and 20\% for IPAH, 56, 44 and $0 \%$ for CTEPH and 33, 50 and $17 \%$ for controls, respectively. We could not demonstrate any association of this polymorphism with clinical data and disease severity.

\section{Discussion}

In this cross-sectional analysis in a Swiss $\mathrm{PH}$ referral center, we studied the genetic variants of the BMPR2 gene, serotonin and oxide system and their relationship to the various clinical parameters in patients with IPAH and CTEPH in comparison to a control group of similarly exercise-limited patients without $\mathrm{PH}$.

$B M P R 2$ mutations in patients with IPAH are either thought to occur in the setting of low-penetrance germline mutations or may arise de novo [23]. In our cohort, we found only one BMPR2 mutation (p.Met273Arg), sur-
Table 4. Frequencies of the tested 5HTT, 5HTR2a and NO polymorphisms in IPAH $(\mathrm{n}=16)$, CTEPH $(\mathrm{n}=16)$ and control groups $(\mathrm{n}=24)$

\begin{tabular}{|c|c|c|c|c|c|c|}
\hline \multirow[t]{2}{*}{ Subjects } & \multirow{2}{*}{$\begin{array}{l}\text { Type of poly- } \\
\text { morphism } \\
5 \mathrm{HTT}\end{array}$} & \multicolumn{3}{|c|}{$\begin{array}{l}\text { Genotypes } \\
\%\end{array}$} & \multicolumn{2}{|c|}{$\begin{array}{l}\text { Allele fre- } \\
\text { quencies, \% }\end{array}$} \\
\hline & & SS & SL & LL & $\mathrm{S}$ & $\mathrm{L}$ \\
\hline IPAH & & 20 & 47 & 33 & 43 & 57 \\
\hline СТЕРН & & 25 & 69 & 6 & 59 & 41 \\
\hline \multirow[t]{2}{*}{ Controls } & & 25 & 54 & 20 & 52 & 48 \\
\hline & 5HTR2a & $\mathrm{TT}$ & TC & $\mathrm{CC}$ & $\mathrm{T}$ & $\mathrm{C}$ \\
\hline IPAH & & 13 & 67 & 20 & 47 & 53 \\
\hline СТЕРН & & 6 & 56 & 38 & 34 & 66 \\
\hline \multirow[t]{2}{*}{ Controls } & & 25 & 42 & 33 & 46 & 54 \\
\hline & eNOS4a/b & $\mathrm{bb}$ & $\mathrm{ab}$ & aa & $\mathrm{b}$ & $\mathrm{a}$ \\
\hline IPAH & & 67 & 33 & 0 & 83 & 17 \\
\hline СТЕРН & & 63 & 31 & 6 & 78 & 22 \\
\hline \multirow[t]{2}{*}{ Controls } & & 67 & 29 & 4 & 81 & 19 \\
\hline & eNOS298 & $\begin{array}{l}\text { Glu/ } \\
\text { Glu }\end{array}$ & $\begin{array}{l}\text { Glu/ } \\
\text { Asp }\end{array}$ & $\begin{array}{l}\text { Asp/ } \\
\text { Asp }\end{array}$ & Glu & Asp \\
\hline IPAH & & 27 & 53 & 20 & 53 & 47 \\
\hline СТЕРН & & 56 & 44 & 0 & 78 & 22 \\
\hline Controls & & 33 & 50 & 17 & 58 & 42 \\
\hline
\end{tabular}

prisingly not in a patient suffering from $\mathrm{PH}$ but from CAD. This finding is novel and remarkable, and may point towards a role of the BMPR2 pathway in other diseases than $\mathrm{PH}$. A thorough history and clinical examination did not reveal any sign for $\mathrm{PH}$ in this patient or his family. The same mutation was previously described in 1 IPAH case with hypothyroidism [23]. So far, functional studies providing more insight into the consequence of this missense mutation are missing. Some missense mutations, especially when located in the proximity of exon/ intron boundaries, may cause aberrant pre-mRNA splicing due to alternations in sequences recognized by various splicing factors [45]. Using RT-PCR analysis, we have shown this not to be the case for the p.Met273Arg genetic variant. Further analyses have to be performed in order to elucidate the effect of this amino acid exchange on proper receptor function as well as in order to exclude a possible mosaic state of this alternation. However, due to the generally low penetrance of BMPR2 mutations and particularly given the different pathophysiology of $\mathrm{PH}$ 
and $\mathrm{CAD}$, it is difficult to estimate whether this mutation could somehow have contributed to the patient's condition or left ventricular function. Other risk factors, mainly his smoking history with 60 pack-years until his first event, have to be considered.

The lack of any detected BMPR 2 mutations in the present IPAH cohort is unexpected but possible considering that the prevalence of $B M P R 2$ mutations in patients with sporadic PAH is only $11-26 \%[20,23,46]$ and may be even lower, as recently described by Rosenzweig et al. [47] (6.1\%). It must, however, be taken into account that the screening method applied has several limitations. It has a very high detection rate for mutations in the coding regions and exon/intron boundaries, but does not allow for identification of large exonic deletions or duplications. The latter are however rare in patients with sporadic $\mathrm{PAH}$, in agreement with a previous study (6 of 126 IPAH patients) [48] and based on our own observations (data not published). Furthermore, putative mutations in the untranslated regulatory and intronic sequences of the $B M P R 2$ gene remain undetected [49].

Another possible explanation might be the comparatively advanced age of the IPAH patients included in our cohort, with average age of disease onset being $61 \pm 16$ years. Based on other observations, BMPR2 mutation carriers are suspected to develop the symptoms earlier than non-carriers [50].

Beside the rare and pathologic mutations, several polymorphic variants have also been identified in the sequence of the BMPR2 gene [23, 51,52]. The frequencies of some of these polymorphisms were studied in several cohorts of PAH patients and unaffected individuals [23]. The c.600A $\rightarrow$ C (p.L200L) polymorphism in exon 5 was found in $4 \%$ of our controls but in $20 \%$ of IPAH patients, and it was associated with a significantly lower $6 \mathrm{MWD}$ and QoL in physical domains (fig. 1). Herewith, we describe for the first time a higher prevalence of a coding $B M P R 2$ polymorphism in an IPAH cohort with an association to disease severity (assessed by the $6 \mathrm{MWD}$ and QoL). As this single-nucleotide polymorphism does not lead to the amino acid exchange and is not predicted to alternate mRNA splicing, it may not have direct causal effects, but may be linked in some patients to another not yet identified functional alternation in the BMPR2 gene. This novel finding may suggest that some common genetic variants of the $B M P R 2$ gene could play a role in the modulation of disease severity. In our small cohort, carriers of any BMPR2 polymorphism were more likely to have a worse outcome after $\mathrm{PH}$ diagnosis (67\% of the patients who died in our cohort were carriers of any poly- morphism compared with $38 \%$ of the survivors); however, these results have to be verified by investigations in larger PH cohorts.

The L-allelic variant of 5-HTT has been found to be associated with disease severity in $\mathrm{PH}$ related to chronic obstructive lung disease [27,53]; however, this association could not be found in IPAH or familial PAH [28]. In our collective, the L-allelic variant was slightly more prevalent in IPAH compared with CTEPH or controls; however, there was no association with clinical parameters or event-free survival. The base in nucleotide position 102 of the 5-HTR2A gene may be thymine (T) or cytosine (C), with three possible genotypes, TT, TC or CC. This sequence variant does not result in any amino-acid change, as both alleles code for a serine in codon 34 , but it is supposed to be in linkage disequilibrium with functional 5HTR2A gene variants. However, we found no difference in the prevalence and clinical presentation according to 5-HTR2A variants in $\mathrm{PH}$ or controls. Our findings discourage a relevant pathogenetic role of the presently investigated 5-HTT and 5-HTR2A polymorphisms in IPAH or CTEPH.

The allelic frequency of the eNOS4a variant in the present cohort was comparable to Japanese patients with high-altitude pulmonary edema and higher than expected from previously described healthy controls (table 4) [36], demonstrating a genetic heterogeneity in various populations of different ethnicity. A tendency towards higher pulmonary vascular resistance and lower exercise capacity assessed by $6 \mathrm{MWD}$ in eNOS4a carriers may point towards a possibly modulating role of this eNOS variant in PH. Concerning the p.Glu298Asp polymorphism, the Asp allelic frequency in CTEPH patients in our cohort was similar to that found in Japanese patients with high-altitude pulmonary edema [36]. However, the frequencies of the Asp allele in IPAH and controls were even higher and similar to a French population [54]. Considering the lack of any association of the p.Glu298Asp polymorphism with clinical parameters, we suggest that this polymorphism might not be significantly involved in the pathogenesis of $\mathrm{PH}$.

Our single center, cross-sectional study bears several intrinsic limitations. First, the investigated cohort is small; however, $\mathrm{PH}$ is a rare disease and significant findings in a small cohort may help to direct future research in the field. Our control group consisted of exercise-limited patients with some form of left heart involvement without $\mathrm{PH}$ and not healthy controls. However, as BMPR2 mutations are thought to be disease specific for PAH, we did not expect to find any pathologic BMPR2 alteration 
in a patient with CAD. The genetic analyses of our patients were restricted to the screening for genetic variants in BMPR2 and in three genes of the serotonin and $\mathrm{NO}$ systems. However, it might be possible that other herein not investigated polymorphisms are causally involved in the pathogenesis of $\mathrm{PH}$.

Overall, the present study may reflect the clinical status and genetic background in a typical PH cohort as seen in a single, tertiary care, referral center. We suggest that the results obtained in this study require verification in a larger case-control study before any definitive conclusions can be made with respect to the current practical relevance.

\section{Acknowledgment}

We thank the Velux Foundation (Zurich, Switzerland) for financial support of the study.

\section{References}

1 Simonneau G, Galie N, Rubin LJ, Langleben D, Seeger W, Domenighetti G, Gibbs S, Lebrec D, Speich R, Beghetti M, Rich S, Fishman A: Clinical classification of pulmonary hypertension. J Am Coll Cardiol 2004;43: $5 \mathrm{~S}-12 \mathrm{~S}$.

$\checkmark 2$ Humbert M, Morrell NW, Archer SL, Stenmark KR, MacLean MR, Lang IM, Christman BW, Weir EK, Eickelberg O, Voelkel NF, Rabinovitch M: Cellular and molecular pathobiology of pulmonary arterial hypertension. J Am Coll Cardiol 2004;43:13S$24 \mathrm{~S}$.

- 3 Fuster V, Steele PM, Edwards WD, Gersh BJ, McGoon MD, Frye RL: Primary pulmonary hypertension: natural history and the importance of thrombosis. Circulation 1984; 70:580-587.

4 Voelkel NF, Tuder RM: Cellular and molecular mechanisms in the pathogenesis of severe pulmonary hypertension. Eur Respir J 1995; 8:2129-2138.

5 Bonderman D, Nowotny R, Skoro-Sajer N, Jakowitsch J, Adlbrecht C, Klepetko W, Lang IM: Bosentan therapy for inoperable chronic thromboembolic pulmonary hypertension. Chest 2005;128:2599-2603.

- 6 Bresser P, Fedullo PF, Auger WR, Channick RN, Robbins IM, Kerr KM, Jamieson SW, Rubin LJ: Continuous intravenous epoprostenol for chronic thromboembolic pulmonary hypertension. Eur Respir J 2004;23: 595-600.

-7 Hoeper MM, Kramm T, Wilkens H, Schulze C, Schafers HJ, Welte T, Mayer E: Bosentan therapy for inoperable chronic thromboembolic pulmonary hypertension. Chest 2005; 128:2363-2367.

$\checkmark$ Nagaya N, Sasaki N, Ando M, Ogino H, Sakamaki F, Kyotani S, Nakanishi N: Prostacyclin therapy before pulmonary thromboendarterectomy in patients with chronic thromboembolic pulmonary hypertension. Chest 2003;123:338-343.

-9 Ulrich S, Speich R, Domenighetti G, Geiser T, Aubert JD, Rochat T, Huber L, Treder U, Fischler M: Bosentan therapy for chronic thromboembolic pulmonary hypertension. A national open label study assessing the effect of Bosentan on haemodynamics, exercise capacity, quality of life, safety and tolerability in patients with chronic thromboembolic pulmonary hypertension (BOCTEPH-Study). Swiss Med Wkly 2007; 137:573-580.

10 Ulrich S, Fischler M, Speich R, Popov V, Maggiorini M: Chronic thromboembolic and pulmonary arterial hypertension share acute vasoreactivity properties. Chest 2006; 130:841-846.

11 Moser KM, Bloor CM: Pulmonary vascular lesions occurring in patients with chronic major vessel thromboembolic pulmonary hypertension. Chest 1993;103:685-692.

12 Lane KB, Machado RD, Pauciulo MW, Thomson JR, Phillips JA 3rd, Loyd JE, Nichols WC, Trembath RC: Heterozygous germline mutations in BMPR2, encoding a TGFbeta receptor, cause familial primary pulmonary hypertension. The International PPH Consortium. Nat Genet 2000;26:8184.

13 Deng Z, Morse JH, Slager SL, Cuervo N, Moore KJ, Venetos G, Kalachikov S, Cayanis E, Fischer SG, Barst RJ, Hodge SE, Knowles JA: Familial primary pulmonary hypertension (gene PPH1) is caused by mutations in the bone morphogenetic protein receptor-II gene. Am J Hum Genet 2000;67:737-744.

14 Newman JH, Wheeler L, Lane KB, Loyd E, Gaddipati R, Phillips JA 3rd, Loyd JE: Mutation in the gene for bone morphogenetic protein receptor II as a cause of primary pulmonary hypertension in a large kindred. N Engl J Med 2001;345:319-324.

15 Yang J, Davies RJ, Southwood M, Long L, Yang X, Sobolewski A, Upton PD, Trembath RC, Morrell NW: Mutations in bone morphogenetic protein type II receptor cause dysregulation of Id gene expression in pulmonary artery smooth muscle cells: implications for familial pulmonary arterial hypertension. Circ Res 2008;102:1212-1221.

16 Nasim MT, Ghouri A, Patel B, James V, Rudarakanchana N, Morrell NW, Trembath RC: Stoichiometric imbalance in the receptor complex contributes to dysfunctional BMPR-II mediated signalling in pulmonary arterial hypertension. Hum Mol Genet 2008; 17:1683-1694.

17 Koehler R, Grunig E, Pauciulo MW, Hoeper MM, Olschewski H, Wilkens H, Halank M, Winkler J, Ewert R, Bremer H, Kreuscher S, Janssen B, Nichols WC: Low frequency of BMPR2 mutations in a German cohort of patients with sporadic idiopathic pulmonary arterial hypertension. J Med Genet 2004;41: e127.

18 Thomson JR, Machado RD, Pauciulo MW, Morgan NV, Humbert M, Elliott GC, Ward K, Yacoub M, Mikhail G, Rogers P, Newman J, Wheeler L, Higenbottam T, Gibbs JS, Egan J, Crozier A, Peacock A, Allcock R, Corris P, Loyd JE, Trembath RC, Nichols WC: Sporadic primary pulmonary hypertension is associated with germline mutations of the gene encoding BMPR-II, a receptor member of the TGF-beta family. J Med Genet 2000;37:741745.

19 Newman JH, Phillips JA 3rd, Loyd JE: Narrative review: the enigma of pulmonary arterial hypertension: new insights from genetic studies. Ann Intern Med 2008;148:278-283.

-20 Newman JH, Trembath RC, Morse JA, Grunig E, Loyd JE, Adnot S, Coccolo F, Ventura C, Phillips JA 3rd, Knowles JA, Janssen B, Eickelberg O, Eddahibi S, Herve P, Nichols WC, Elliott G: Genetic basis of pulmonary arterial hypertension: current understanding and future directions. J Am Coll Cardiol 2004;43:33S-39S.

21 Roberts KE, McElroy JJ, Wong WP, Yen E, Widlitz A, Barst RJ, Knowles JA, Morse JH: BMPR2 mutations in pulmonary arterial hypertension with congenital heart disease. Eur Respir J 2004;24:371-374.

22 Runo JR, Vnencak-Jones CL, Prince M, Loyd JE, Wheeler L, Robbins IM, Lane KB, Newman JH, Johnson J, Nichols WC, Phillips JA III: Pulmonary veno-occlusive disease caused by an inherited mutation in bone morphogenetic protein receptor II. Am J Respir Crit Care Med 2003;167:889-894.

23 Machado RD, Aldred MA, James V, Harrison RE, Patel B, Schwalbe EC, Gruenig E, Janssen B, Koehler R, Seeger W, Eickelberg O, Olschewski H, Elliott CG, Glissmeyer E, 
Carlquist J, Kim M, Torbicki A, Fijalkowska A, Szewczyk G, Parma J, Abramowicz MJ, Galie N, Morisaki H, Kyotani S, Nakanishi N, Morisaki T, Humbert M, Simonneau G, Sitbon O, Soubrier F, Coulet F, Morrell NW, Trembath RC: Mutations of the TGF-beta type II receptor BMPR2 in pulmonary arterial hypertension. Hum Mutat 2006;27:121132.

-24 Suntharalingam J, Machado RD, Sharples LD, Toshner MR, Sheares KK, Hughes RJ, Jenkins DP, Trembath RC, Morrell NW, Pepke-Zaba J: Demographic features, BMPR2 status and outcomes in distal chronic thromboembolic pulmonary hypertension. Thorax 2007;62:617-622.

-25 Eddahibi S, Morrell N, d'Ortho MP, Naeije R, Adnot S: Pathobiology of pulmonary arterial hypertension. Eur Respir J 2002;20: 1559-1572.

-26 Eddahibi S, Raffestin B, Hamon M, Adnot S: Is the serotonin transporter involved in the pathogenesis of pulmonary hypertension? J Lab Clin Med 2002;139:194-201.

-27 Eddahibi S, Chaouat A, Morrell N, Fadel E, Fuhrman C, Bugnet AS, Dartevelle P, Housset B, Hamon M, Weitzenblum E, Adnot S: Polymorphism of the serotonin transporter gene and pulmonary hypertension in chronic obstructive pulmonary disease. Circulation 2003; 108:1839-1844.

28 Machado RD, Koehler R, Glissmeyer E, Veal C, Suntharalingam J, Kim M, Carlquist J, Town M, Elliott CG, Hoeper M, Fijalkowska A, Kurzyna M, Thomson JR, Gibbs SR, Wilkins MR, Seeger W, Morrell NW, Gruenig E, Trembath RC, Janssen B: Genetic association of the serotonin transporter in pulmonary arterial hypertension. Am J Respir Crit Care Med 2006;173:793-797.

29 Leonard BE: Sub-types of serotonin receptors: biochemical changes and pharmacological consequences. Int Clin Psychopharmacol 1992;7:13-21.

- 30 Liolitsa D, Powell JF, Prince M, Lovestone S: Association study of the 5-HT(2A) receptor gene polymorphism, T102C and essential hypertension. J Hum Hypertens 2001; 15: 335-339.

- 31 Vaquero Lorenzo C, Baca-Garcia E, DiazHernandez M, Botillo-Martin C, PerezRodriguez MM, Fernandez-Ramos C, Saiz-Gonzalez MD, Quintero-Gutierrez FJ, Saiz-Ruiz J, Fernandez Piqueras J, Gonzalez de Rivera JL, de Leon J: Association between the T102C polymorphism of the serotonin2A receptor gene and schizophrenia. Prog Neuropsychopharmacol Biol Psychiatry 2006;30:1136-1138.

- 32 Yamada S, Akita H, Kanazawa K, Ishida T, Hirata K, Ito K, Kawashima S, Yokoyama M: T102C polymorphism of the serotonin (5HT) 2A receptor gene in patients with nonfatal acute myocardial infarction. Atherosclerosis 2000;150:143-148.
33 Ghofrani HA, Pepke-Zaba J, Barbera JA, Channick R, Keogh AM, Gomez-Sanchez MA, Kneussl M, Grimminger F: Nitric oxide pathway and phosphodiesterase inhibitors in pulmonary arterial hypertension. J Am Coll Cardiol 2004;43:68S-72S.

34 Giaid A, Saleh D: Reduced expression of endothelial nitric oxide synthase in the lungs of patients with pulmonary hypertension. $\mathrm{N}$ Engl J Med 1995;333:214-221.

35 Casas JP, Bautista LE, Humphries SE, Hingorani AD: Endothelial nitric oxide synthase genotype and ischemic heart disease: metaanalysis of 26 studies involving 23,028 subjects. Circulation 2004;109:1359-1365.

36 Droma Y, Hanaoka M, Ota M, Katsuyama Y Koizumi T, Fujimoto K, Kobayashi T, Kubo $\mathrm{K}$ : Positive association of the endothelial nitric oxide synthase gene polymorphisms with high-altitude pulmonary edema. Circulation 2002;106:826-830.

37 Ahsan A, Mohd G, Norboo T, Baig MA, Pasha MA: Heterozygotes of NOS3 polymorphisms contribute to reduced nitrogen oxides in high-altitude pulmonary edema. Chest 2006;130:1511-1519.

38 Smith EM, Baillie JK, Thompson AA, Irving JB, Porteous D, Webb DJ: Endothelial nitric oxide synthase polymorphisms do not influence pulmonary artery systolic pressure at altitude. High Alt Med Biol 2006;7:221-227.

39 Hoeper MM, Mayer E, Simonneau G, Rubin LJ: Chronic thromboembolic pulmonary hypertension. Circulation 2006;113:20112020

40 Cenedese E, Speich R, Dorschner L, Ulrich S, Maggiorini M, Jenni R, Fischler M: Measurement of quality of life in pulmonary hypertension and its significance. Eur Respir J 2006;28:808-815.

41 Ruegg C, Hersberger M, Wusk B, Rentsch K, Kullak-Ublick GA, von Eckardstein A, Maly FE: Detection of the Arg702Trp, Gly908Arg and Leu1007fsinsC polymorphisms of the NOD2/CARD15 gene by real-time PCR with melting curve analysis. Clin Chem Lab Med 2004;42:494-498.

-42 Wang XL, Sim AS, Badenhop RF, McCredie RM, Wilcken DE: A smoking-dependent risk of coronary artery disease associated with a polymorphism of the endothelial nitric oxide synthase gene. Nat Med 1996;2:41-45.

43 Hersberger M, Marti-Jaun J, Rentsch K, Hanseler E: Rapid detection of the CYP2D6*3, CYP2D6*4, and CYP2D6*6 alleles by tetra-primer PCR and of the CYP2D6*5 allele by multiplex long PCR Clin Chem 2000;46:1072-1077.

44 Muntwyler J, Marti-Jaun J, Luscher TF, Hanseler E, Hersberger M: The Asp298 but not the C-786 genotype of the endothelial nitric oxide synthase is reduced with age in healthy Swiss men. Clin Chem Lab Med 2005;43: 971-973.
45 Cartegni L, Chew SL, Krainer AR: Listening to silence and understanding nonsense: exonic mutations that affect splicing. Nat Rev Genet 2002;3:285-298.

46 Morse JH: Genetic studies of pulmonary arterial hypertension. Lupus 2003;12:209212.

47 Rosenzweig EB, Morse JH, Knowles JA, Chada KK, Khan AM, Roberts KE, McElroy JJ, Juskiw NK, Mallory NC, Rich S, Diamond B, Barst RJ: Clinical implications of determining BMPR2 mutation status in a large cohort of children and adults with pulmonary arterial hypertension. J Heart Lung Transplant 2008;27:668-674

48 Aldred MA, Vijayakrishnan J, James V, Soubrier F, Gomez-Sanchez MA, Martensson G, Galie N, Manes A, Corris P, Simonneau G, Humbert M, Morrell NW, Trembath RC: BMPR2 gene rearrangements account for a significant proportion of mutations in familial and idiopathic pulmonary arterial hypertension. Hum Mutat 2006;27:212-213.

49 Aldred MA, Machado RD, James V, Morrell NW, Trembath RC: Characterization of the BMPR2 5'-untranslated region and a novel mutation in pulmonary hypertension. Am J Respir Crit Care Med 2007;176:819-824.

50 Sztrymf B, Coulet F, Girerd B, Yaici A, Jais X, Sitbon O, Montani D, Souza R, Simonneau G, Soubrier F, Humbert M: Clinical outcomes of pulmonary arterial hypertension in carriers of BMPR2 mutation. Am J Respir Crit Care Med 2008;177:1377-1383.

-51 Machado RD, Pauciulo MW, Thomson JR, Lane KB, Morgan NV, Wheeler L, Phillips JA 3rd, Newman J, Williams D, Galie N, Manes A, McNeil K, Yacoub M, Mikhail G, Rogers P, Corris P, Humbert M, Donnai D, Martensson G, Tranebjaerg L, Loyd JE, Trembath RC, Nichols WC: BMPR2 haploinsufficiency as the inherited molecular mechanism for primary pulmonary hypertension. Am J Hum Genet 2001;68:92-102.

52 Morisaki H, Nakanishi N, Kyotani S, Takashima A, Tomoike H, Morisaki T: BMPR2 mutations found in Japanese patients with familial and sporadic primary pulmonary hypertension. Hum Mutat 2004;23:632.

53 Ulrich S, Hersberger M, Fischler M, Nussbaumer-Ochsner Y, Treder U, Russi EW, Speich R: Genetic polymorphisms of the serotonin transporter, but not the 2 a receptor or nitric oxide synthetase, are associated with pulmonary hypertension in COPD. Respiration 2010;79:288-295.

-54 Lacolley P, Gautier S, Poirier O, Pannier B, Cambien F, Benetos A: Nitric oxide synthase gene polymorphisms, blood pressure and aortic stiffness in normotensive and hypertensive subjects. J Hypertens 1998;16:31-35. 